Vol.1, No.1, Desember 2017

E-mail: jpsp@unpad.ac.id

\title{
PEMAKNAAN LOYALITAS KARYAWAN PADA GENERASI X DAN GENERASI Y (Studi Pada Karyawan Di Indonesia)
}

\author{
Ayu Dwi Nindyati \\ Universitas Paramadina \\ ayu.nindyati@paramadina.ac.id
}

\begin{abstract}
ABSTRAK
Beberapa survey menjelaskan tidak kurang dari 30\% angkatan kerja saat ini adalah generasi $Y$ (gen $Y$ ) dengan segala karakteristik yang ada. Perusahaan saat ini didominasi kombinasi antara generasi $X($ gen $X)$ dan gen $Y$, yang masing-masing generasi memiliki karakteristik yang berbeda. Lingkungan dan perkembangan teknologi di tempat bekerja para gen $X$ dan gen $Y$ membentuk karakteristik yang berbeda. Dalam dunia Industri, salah satu yang menjadi perbincangan adalah loyalitas karyawan yang dipahami sebagai keyakinan karyawan atas pilihannya dalam mendukung kesuksesan organisasi tempatnya bekerja. Secara singkat karyawan yang loyal memberikan indikator perilaku bersedia untuk menetap dalam organsasi tempatnya bekerja. Penelitian ini bertujuan untuk menggali pemaknaan akan loyalitas pada gen $\mathrm{X}$ dan gen $\mathrm{Y}$, dengan harapan dapat membantu manajemen untuk mengelola karyawannya. Penelitian dilakukan dengan metode survey pada 108 karyawan gen $Y(L=42$ dan $P=66)$ dan 88 karyawan gen $X(L=33$ dan $P=55)$ di beberapa kota besar di Indonesia (Jakarta, Bandung, Yogyakarta, Semarang, Denpasar, Solo, Manado dan Surabaya). Ratarata usia gen $Y$ adalah 29 tahun dan gen $X$ adalah 43 tahun. Hasil utama penelitian ini menjelaskan bahwa baik gen $X$ dan gen $Y$ memiliki perbedaan yang signifikan tentang tingkat kepentingan loyalitas karyawan. Gen $X$ menyatakan bahwa loyalitas lebih penting dibandingkan pada gen $\mathrm{Y}$ (Mean gen $\mathrm{X}=$ 4 dan Mean gen $Y=3,77$ ). Secara frekwensi pindah bekerja memang gen $Y$ memiliki pengalaman pindah kerja yang lebih besar dibandingkan gen $X$. Pada gen $Y$ loyalitas lebih dipandang pada bagaimana karyawan komit dan bertanggung jawab secara profesionalitas terhadap tugasnya dengan dilandasi kompetensi yang tepat. Gen X memandang loyalitas berkaitan dengan bagaimana karyawan menjalankan fungsinya yang berorientasi pada kemajuan organisasi atau pencapaian tujuan organisasi. Artinya bahwa pada gen $\mathrm{Y}$ lebih focus pada pengembangan karir dalam dirinya sedangkan dalam gen $X$ ketika berorientasi pada pengembangan karir adalah mengarah kepada pengembangan organisasinya.
\end{abstract}

Kata kunci: Gen X, Gen Y, Pemaknaan (meaning), Loyalitas

\section{ABSTRACT}

Surveys shown almost $30 \%$ of work force were generation $Y$ (gen $Y$ ), meanwhile many companies dominated by gen $X$ and gen $Y$, each generation have different characteristics. Environment and IT development at work place effect this difference. One of the most topic in Industrial and Organizational was employee loyalty. The employee loyalty in this research understood as an employee's belief in his choice to support the success of the organization. This study aims to explore the meaning of loyalty in gen $X$ and gen $Y$, to help management to manage its employees. The research was conducted by survey method on 108 employees of gen $Y(M=42$ and $F=66)$ and 88 employees of gen $X(M=33$ and $F=55$ ) in several cities in Indonesia (Jakarta, Bandung, Yogyakarta, Semarang, Denpasar, Solo, Manado and Surabaya). The average age of the gen $Y$ is 29 years old and the gen $X$ is 43 years old. The main results of this study explain that both gen $X$ and gen $Y$ have significant differences regarding the level of importance of employee loyalty. Gen $X$ states that loyalty is more important than gen $Y$ (Mean gen $X=4$ and Mean Gen $Y=3.77$ ). By the frequency of moving to work (mobility), gen $Y$ have a greater job change experience than gen $X$. In the gen $Y$ loyalty is more viewed in how employees commit and professionally responsible for their tasks based on the right competencies. Gen $X$ views loyalty about how employees perform their functions that are oriented towards organizational progress or achieving organizational goals. Its means gen $Y$ saw career development more focus for themselves while the gen $X$ saw career development as leading to the development of the organization.

Keywords: Gen X, Gen Y, Meaning, Loyalty 


\section{Journal of Psychological Science and Profesion (JPSP)}

Vol.1, No.1, Desember 2017

E-mail: jpsp@unpad.ac.id

\section{PENDAHULUAN}

Badan Pusat Statistik (BPS) mencatat komposisi penduduk usia produktif 15-35 tahun saat ini mencapai 40 persen dari total jumlah penduduk Indonesia. Jumlah ini diperkirakan melonjak 50 hingga 60 persen hingga 2020 mendatang (BPS, 2016). Sebaran demografis seperti yang dipaparkan BPS tentunya merupakan hal bagus yang artinya Indonesia tidak akan kekurang sumber daya manusia (SDM) dengan catatan dapat diimbangi kualitasnya. Sebaliknya bila kualitas SDM ini tidak dapat diupayakan maka kita akan mendapatkan sebaran yang tidak seimbang dimana satu orang produktif akan menanggung beban empat orang yang tidak produktif. Salah satu konsekwensi yang muncul adalah adanya generasi yang berbeda dalam angkatan kerja tersebut yang dikenal dengan generasi matures (lahir sebelum tahun1945), baby boomers (lahir dari tahun 1945 - 1962), gen X (1963 - 1982), dan gen Y(1983 - 1997 ( (Ball \& Gotsill, 2011) dan gen Z (pada umumnya lahir setelah tahun 2000) ( (Yigit \& Aksay, 2015).

Penggolongan generasi karyawan tersebut juga menambah keragaman dalam angkatan kerja, bukan hanya terbatas pada jenis kelamin, Pendidikan, agama maupun budaya. Keragaman angkatan kerja saat ini bertambah variannya yaitu dengan mulai masuknya gen $Y$ (gen $Y$ ) ke dalam angkatan kerja. Kondisi perusahaan saat ini pada umumnya memiliki karyawan yang mixed antara gen $Y$ dan gen $X$. Seperti yang dijelaskan oleh Ball dan Gotsill (2011) bahwa generasi baby boomers akan terdesak oleh angkatan kerja gen $\mathrm{X}$ dan gen $\mathrm{Y}$ dan bahkan hasil survey pada tahun 2012 dari lembaga training RedTree Leadership di Utah, Amerika Serikat, menjelaskan bahwa pada tahun 2020 angkatan kerja di dunia itu sudah tidak melibatkan generasi matures (builders) dan mulai dimasuki oleh gen Z (http://www.redtreeleadership.com/ , unduh 25 Oktober 2017). Selain itu Ismail, Rahim, Hou Lee, dan Tahir (2016) menjelaskan bahwa dalam perusahaan manufactur di Asia Tenggara sejak 1990 telah memiliki karyawan gen $Y$ dalam jumlah yang besar melengkapi karyawan gen $X$ yang telah ada sebelumnya. Artikel ini akan fokus pada gen $X$ dan gen $Y$ karena gen $X$ dan gen $Y$ adalah generasi yang memiliki jumlah besar saat ini dalam angkatan kerja di Indonesia.

Gen X dikenal sebagai generasi yang menunjukkan kemandirian dan bekerja dengan dilandasi oleh adanya aturan yang jelas namun tidak kaku. Gen X mementingkan adanya kejelasan informasi bila berkaitan dengan karir yang dimilikinya. Suasana kerja yang nyaman dan juga memberikan kebebasan untuk menyelesaikan tugasnya merupakan aspek yang akan membantunya tetap bersemangat dalam mengerjakan tugasnya. Ketertarikannya pada efisiensi membuatnya tidak anti dengan kemajuan teknologi yang akan membantu membuat cara kerja yang efisien. Konsep loyalitas telah tertanam dalam benak para gen $X$ karena adanya pengalaman untuk mendapatkan income yang tetap dalam tahun-tahun sulit perekonomian pada akhir tahun 1970an dan awal tahun 1980an apalagi dengan banyaknya fenomena pengangguran yang muncul baik karena ada PHK maupun tidak tersedianya lapangan kerja (Ball \& Gotsill, 2011).

Gen $Y$ dikenal dengan generasi digital natives. Gen $Y$ lahir dalam era digital yang memungkinkan untuk mendapatkan informasi dari berbagai daerah dalam hitungan detik. Gen $Y$ terbiasa mendapatkan informasi dengan cepat, sehingga dalam kehidupan kerja, gen $Y$ ini termasuk generasi yang tidak suka dengan kata-kata 'wait', dengan alasan ini gen $Y$ dikenal sebagai generasi yang tidak sabar. Karir bagi gen $\mathrm{Y}$ bukanlah berada dalam satu perusahaan yang harus ditunggu pencapaiannya. Dalam pekerjaan gen $Y$ menghargai adanya keragaman dan menyenangi berada di dalamnya, karena dengan keragaman ini gen $Y$ akan mendapatkan berbagai masukan dan pengetahuan tambahan. Gen $Y$ sangat senang berada dalam perusahaan yang memiliki misi dan focus yang kuat bukan hanya pada kinerja perusahaan namun juga peduli akan kondisi lingkungan pada umumnya, sehingga gen $Y$ ini sangat senang berada dalam perusahaan yang memperhatikan isu lingkungan seperti memasyarakatkan kegiatan 'recycle, reduce dan reuse' (Ball \& Gotsill, 2011).

Mixed generation dalam tempat kerja bukan hal baru, Ball dan Gotsill (2011) menjelaskan, setidaknya ada empat hal yang harus diperhatikan oleh organisasi/perusahaan yang memiliki karyawan mixed generation ini, yaitu 1) perhatikan trends kehidupan sosial pada generasinya yang mencerminkan dirinya apa adanya, 2) pahami bagaimana trends ini akan membentuk atau memengaruhi gaya belajar dan kerjanya, 3) bantu para pekerja memahami dan membawa nilai-nilai (values) sesuai generasinya ke dalam diskusi atau forum dalam perusahaan dan 4) berikan fasilitas untuk transfer knowledge terkait dengan hal apa saja yang meaningful dari setiap generasi baik bagi seorang yang sudah ahli maupun belum. Berdasarkan apa yang disampaikan Ball dan Gotsill tersebut, maka 


\section{Journal of Psychological Science and Profesion (JPSP)}

Vol.1, No.1, Desember 2017

E-mail: jpsp@unpad.ac.id

organisasi atau perusahaan perlu memahami dan memberikan perhatian yang besar terkait dengan bagaimana menyiasati pengelolaannya termasuk ketika terjadi gap pemaknaan akan sikap kerja antar generasi tersebut, sebagai contohnya adalah tentang loyalitas.

Beberapa hasil penelitian sebelumnya sudah menegaskan bahwa bila berkaitan dengan loyalitas maka gen $Y$ bukan generasi yang memiliki loyalitas bagus, bahka sering disebut sebagai generasi yang disloyal (Hobart, 2016), generasi yang kurang dalam sense of belonging terhadap organisasi (Puteh, Kaliannan, \& Alam, 2015), dan gen $Y$ juga memiliki values yang mendasar terkait dengan pengembangan diri dan karirnya sehingga lebih memiliki mobilitas dibandingkan gen $X$, yang artinya lebih mudah untuk pindah pekerjaan dibandingkan berada dalam satu perusahaan untuk meniti karir sampai jabatan tertentu (Ismail, Rahim, Hou Lee, \& Tahir, 2016). Berdasarkan penelitian-penelitian dan fenomena yang ada, loyalitas karyawan merupakan aspek yang menarik untuk dikaji lebih mendalam dengan menyertakan generasi karyawan yang ada, dalam hal ini adalah gen $X$ dan gen $\mathrm{Y}$.

Perlu dipahami terlebih dulu terkait dengan definisi loyalitas sebelum mengkaji lebih mendalam terkait dengan pemaknaan pada setiap generasi. Loyalitas dijelaskan oleh The Loyalty Research Center (1990) sebagai adanya karyawan yang menyatakan komitmennya akan kesuksesan organisasi/perusahaan dan meyakini bahwa bekerja di perusahaan/organisasi ini merupakan pilihan terbaik. Tidak hanya berencana akan tetap berada dalam perusahaan tersebut, namun juga tidak aktif mencari peluang kerja di tempat lain. Beberapa tokoh menyebutkan bahwa loyalitas merupakan bentuk lain dari organizational citizenship behavior (OCB) (Bettencourt, Gwinner, \& Meuter, 2001); perwujudan dari komitmen organisasi, merupakan individual identifikasi dan keterlibatan dengan organisasi tertentu (Mowday, Porter, \& Steers, 1982); dan Meyer dan Allen (1991) menjelaskan bahwa loyalitas merupakan perwujudan komitmen organisasi namun tidak terbatas pada sikap karyawan terhadap organsasi. Loyalty lebih mengarah kepada adanya willingness untuk tetap berada dalam organisasi/perusahaan.

Berdasarkan berbagai pemahaman tentang loyalitas tersebut, peneliti memahami bahwa loyalitas merupakan perwujudan dari aspek-aspek perilaku organsasi lainnya terutama OCB dan komitmen organisasi, namun memiliki unsur yang lebih mendalam terkait dengan kemauannya untuk tetap berada dalam organisasi. Tidak memperlihatkan tingkah laku yang merugikan organisasi pada akhrinya. Mowday, Porter, and Steers, (1979) menegaskan bahwa loyalitas ini memiliki karakteristik yang berkaitan dengan tiga hal yaitu 1) keyakinan yang kuat (strong belief) dan penerimaan tujuan organisasi dan nilai (values); 2) kemauan untuk menunjukkan usahausaha yang mengatasnamakan perusahaan/organisasi dan 3) adanya kemauan yang kuat untuk menjaga keanggotaannya dalam organisasi.

Pemahaman akan loyalitas karyawan pada perusahaan membawa pada satu kesimpulan bahwa loyalitas karyawan merupakan hal penting yang harus di upayakan oleh setiap perusahaan. Bukan hanya berkaitan dengan produktivitas perusahaan pada umumnya namun untuk aspek yang lebih besar yaitu keberlangsungan dari perusahaan tersebut, karena akan mendapatkan kandidat dalam suksesi kepemimpinan di perusahaan. Di sisi lain, pemahaman akan gen $X$ dan gen $Y$ membawa pada satu kesimpulan, bahwa setiap generasi memiliki karakter yang berbeda, dan ketika bermuara pada loyalitas, setiap generasi memilki pemahaman yang khas. Gen X secara tipikal memiliki orientasi pada memelihara karir dalam satu perusahaan dengan mengedepankan kenyamanan dan kebebasan dalam menjalankan fungsinya. Sementara itu gen Y memposisikan dirinya sebagai generasi yang berorientasi pada kecepatan dalam mengharapkan sesuatu termasuk dalam menjalankan proses tugasnya. Sama dengan gen $X$, gen $Y$ juga mengutamakan kenyamanan dalam bekerja, sehingga sekali gen $Y$ mendapatkan tempat kerja yang cocok, maka gen $\mathrm{Y}$ akan menjaganya. Dengan kondisi tersebut, peneliti melihat bahwa gen $X$ dan gen $Y$ ada kecenderungan memiliki perbedaan makna akan tingkat kepentingan loyalitas karyawan pada perusahaan, sehingga diajukan hipotesis sebagai berikut:

Hipotesis: Ada perbedaan pemaknaan kepentingan loyalitas karyawan pada gen $X$ dan gen $Y$

\section{METODE}

Penelitian ini dilakukan dengan participant para karyawan yang berasal dari lima kota besar di Indonesia yaitu Jakarta, Bandung, Surabaya, Yogyakarta dan Denpasar. Karyawan ini terbagi kedalam gen $X$ sebanyak 88 orang (laki-laki $=33$ dan Perempuan 55) dengan rata-rata usia gen $X$ adalah 42,6 tahun. Gen $Y$ sebanyak 108 orang 


\section{Journal of Psychological Science and Profesion (JPSP)}

Vol.1, No.1, Desember 2017

E-mail: jpsp@unpad.ac.id

(laki-laki $=42$ dan perempuan $=66)$ dengan ratarata usia $Y$ adalah 28, 43. Penelitian dilakukan dengan pendekatan deskriptif dan inferensial. Terkait dengan pendekatan inferensial diberikan satu pertanyaan yang menanyakan seberapa penting loyalitas karyawan menurut partisipan, dengan pilihan jawaban mengikuti skala likert dari sangat tidak penting sampai sangat penting. Selain itu untuk pendekatan deskriptif diajukan pertanyaan-pertanyaan terbuka untuk mengungkap pemaknaan loyalitas karyawan pada gen $\mathrm{X}$ dan gen $\mathrm{Y}$.

Pada gambar 1 dan gambar 2 merupakan gambaran sebaran tahun kelahiran gen $X$ dan gen $Y$ dari partisipan penelitian.

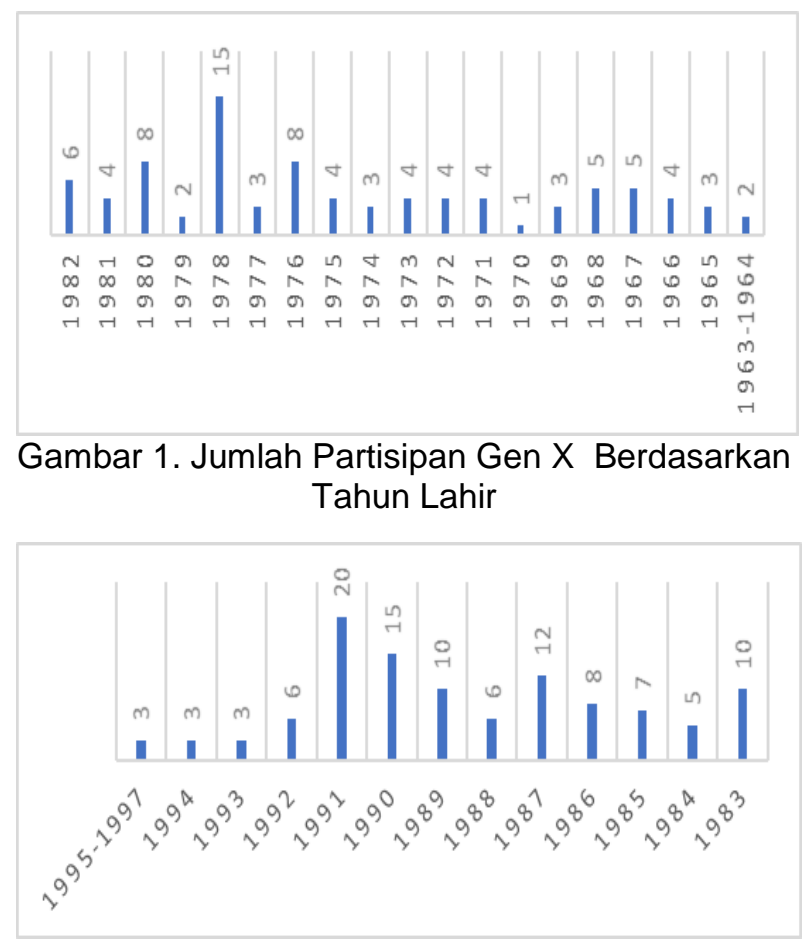

Gambar 2. Jumlah Partisipan Gen Y Berdasarkan Tahun Lahir

\section{HASIL DAN PEMBAHASAN}

Penelitian ini menggunakan analisis varian dua jalur untuk melakukan konfirmasi atas hipotesis penelitian yang diajukan, dengan menggunakan program SPSS 24. Hasil analisis varian dua jalur dapat dilihat pada tabel 1 .
Tabel 1. Hasil analisis varian dua jalur generasi, jenis kelamin dan pentingnya loyalitas

\begin{tabular}{lcccccc}
\multicolumn{7}{c}{ karyawan } \\
\hline Sumber & $\begin{array}{l}\text { Jumlah } \\
\text { Kuadrat }\end{array}$ & Db & $\begin{array}{c}\text { Rerata } \\
\text { Kuadrat }\end{array}$ & $\mathrm{Fe}$ & $\mathrm{p}$ & Interpretasi \\
\hline $\begin{array}{l}\text { Antar Jenis } \\
\text { Kelamin }\end{array}$ & 0,484 & 1 & 0,484 & 0,635 & 0,426 & Non signifikan \\
$\begin{array}{l}\text { Antar } \\
\text { Generasi }\end{array}$ & 2,959 & 1 & 2,959 & 3,888 & 0,050 & Siginifikan \\
$\begin{array}{l}\text { Interaksi } \\
\text { Jenis }\end{array}$ & 0,484 & 1 & 0,484 & 0,635 & 0,426 & Non signifikan \\
$\begin{array}{l}\text { Kelamin } \\
\text { dan } \\
\text { Generasi }\end{array}$ & & & & & & \\
\hline a. R Squared $=0,025$ (Adjusted R Squared $=0,009) ; p=0,188(\mathrm{~ns})$ &
\end{tabular}

Berdasarkan tabel 1, maka diperoleh informasi bahwa pemaknaan loyalitas (penting dan tidaknya loyalitas) pada gen $X$ dan gen $Y$ menunjukkan perbedaan yang signifikan. Sehingga hipotesis yang diajukan dapat terkonfirmasi. Peneliti juga mencoba melihat berdasarkan jenis kelamin dan interaksi antara jenis kelamin dan generasi, namun hasil penelitian menjelaskan bahwa berdasarkan dua kelompok tersebut tidak menunjukkan adanya beda yang signifikan.

Untuk melengkapi tabel 1 dipaparkan hasil analisis deskripsi yang menjelaskan bagaimana mean atau rata-rata loyalitas karyawan berdasarkan jenis kelamin dan generasi yang tersaji dalam tabel 2.

Tabel 2. Rata-rata Loyalitas Karyawan berdasarkan variabel Jenis Kelamin dan Generasi

\begin{tabular}{llccc}
\hline Sumber & Perempuan & $\begin{array}{c}\text { Laki- } \\
\text { laki }\end{array}$ & $\begin{array}{c}\text { Gen } \\
\mathbf{X}\end{array}$ & $\begin{array}{c}\text { Gen } \\
\mathbf{Y}\end{array}$ \\
\hline $\begin{array}{l}\text { Jenis } \\
\text { Kelamin } \\
\text { Generasi }\end{array}$ & 3,92 & 3,80 & & \\
\hline
\end{tabular}

Tabel 2 menjelaskan lebih detail terkait dengan rata-rata loyalitas karyawan bila dilihat dari variabel jenis kelamin dan generasi. Terlihat bahwa nilai rata-rata pentingnya loyalitas karyawan pada perempuan lebih tinggi dibandingkan pada laki-laki. Sedangkan berdasarkan variabel generasi, maka terlihat bahwa gen $X$ memiliki rata-rata pentingnya loyalitas karyawan lebih tinggi dibandinngkan dengan gen $\mathrm{Y}$. Loyalitas yang dimaksud adalah kesetiaan untuk tetap berada dalam organisasi/ perusahaan. Selain melakukan analisis eksplanasi untuk membuktikan hipotesis, penelitian ini melengkapi dengan hasil analisi terhadap pertanyaan terbuka yang diberikan kepad para participant. Pertanyaan pertama yang diajukan adalah berapa kali pindah kerja, hasil 


\section{Journal of Psychological Science and Profesion (JPSP)}

Vol.1, No.1, Desember 2017

E-mail: jpsp@unpad.ac.id

infografis terdapat pada gambar 3 dan 4 sebagai berikut :

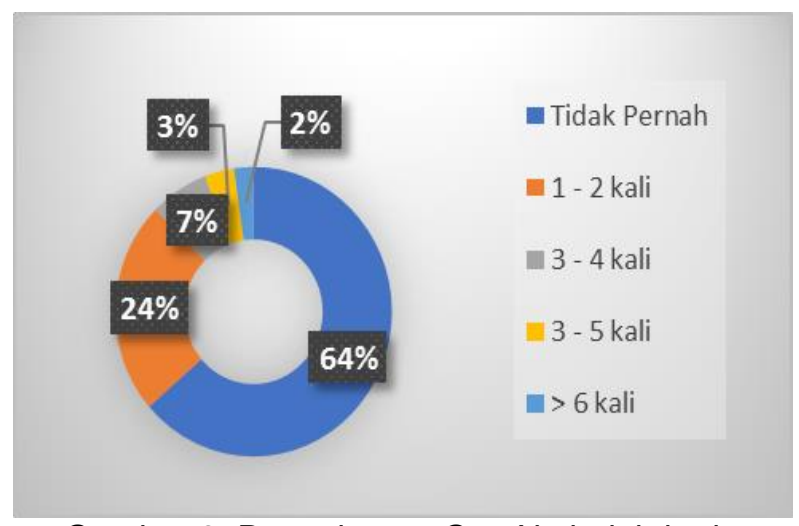

Gambar 3. Pengalaman Gen X pindah kerja

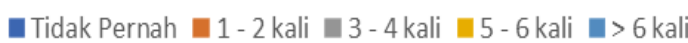

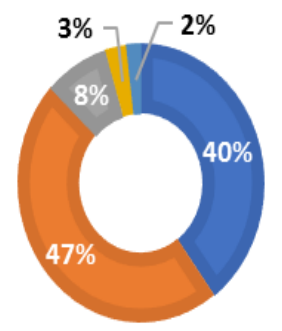

Gambar 4. Pengalaman Gen Y Pindah Kerja

Berdasarkan pada gambar 3 dan 4 menjelaskan bahwa gen $X$ dan gen $Y$ sama-sama memiliki pengalaman pindah kerja 1 sampai lebih dari 6 kali, dan ada juga yang tidak pernah pindah kerja. Aspek yang membedakan adalah frekwensi yang berbeda. Gen X memiliki prosentase yang lebih besar dalam kategori tidak pernah pindah kerja dibandingkan dengan gen $\mathrm{Y}$. Sementara itu pada kategori pindah kerja $1-2$ kali, gen $Y$ memiliki prosentase yang lebih besar dibandingkan dengan gen $\mathrm{X}$. Sedangkan untuk perpindahan yang $3->6$ kali kedua generasi menunjukkan beda tipis.

Pertanyaan kedua yang diajukan adalah alasan para participants pindah pekerjaan. Hal ini dapat dilihat pada gambar 5 dan gambar 6 .

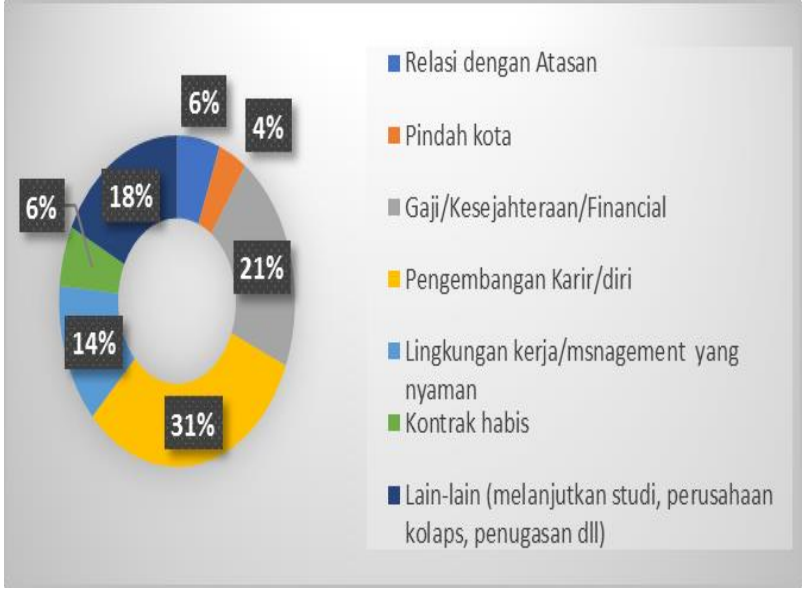

Gambar 5. Alasan Gen X Pindah Kerja

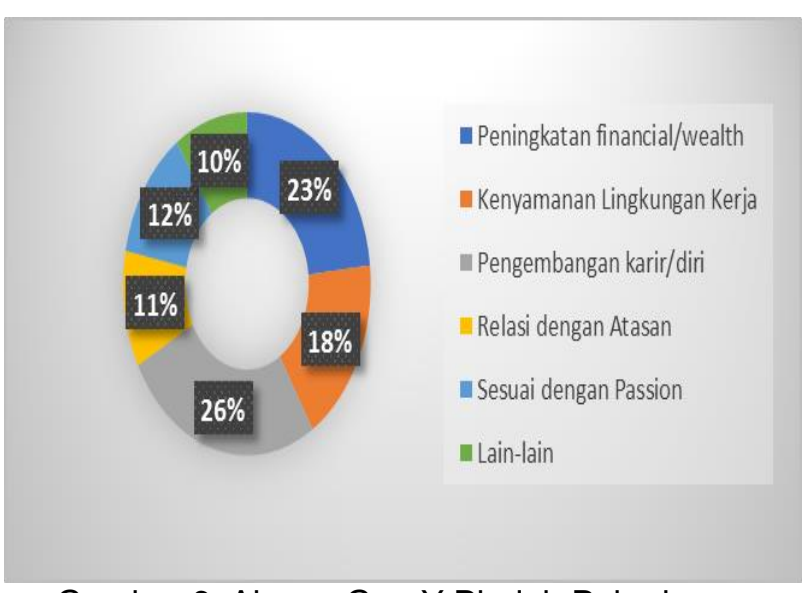

Gambar 6. Alasan Gen Y Pindah Pekerjaan

Gambar 5 dan gambar 6 menjelaskan bahwa prosentase terbesar gen $X$ dan gen $Y$ pindah kerja adalah untuk pengembangan diri, yang kedua adalah berkaitan dengan financial atau besarnya gaji yang didapatkan, yang ketiga untuk gen $X$ menyebutkan relasi dengan atasan sedangakan gen $Y$ menyebutkan kenyamanan tempat kerja. Alasan yang muncul pada gen $Y$ dan tidak muncul pada gen $X$ adalah karena kesesuaian dengan passion atau minat kerjanya.

Pertanyaan ketiga yang diajukan adalah berkaitan dengan sudut pandang setiap partisipan terhadap karyawan yang bekerja di tempat yang sama lebih dari 5 tahun. Dari partisipan diperoleh informasi seperti yang terdapat pada gambar 7 dan gambar 8 . 


\section{Journal of Psychological Science and Profesion (JPSP)}

Vol.1, No.1, Desember 2017

E-mail: jpsp@unpad.ac.id

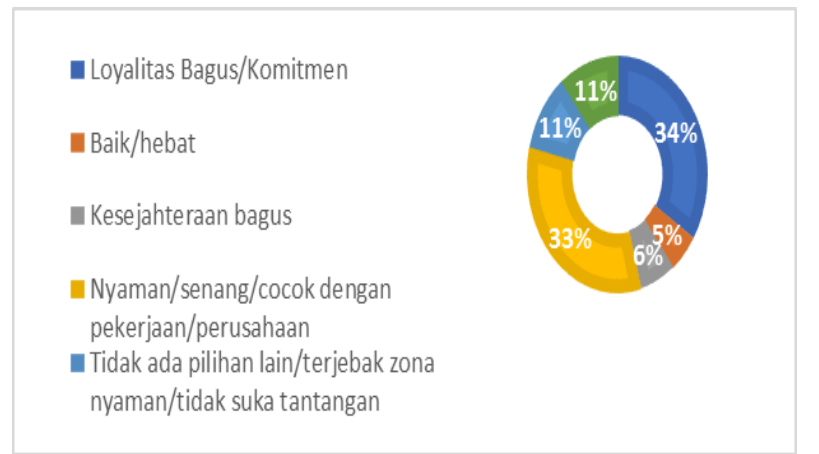
Gambar 7. Gen X memandang karyawan yang bekerja $>5$ tahun
di perusahaan yang sama

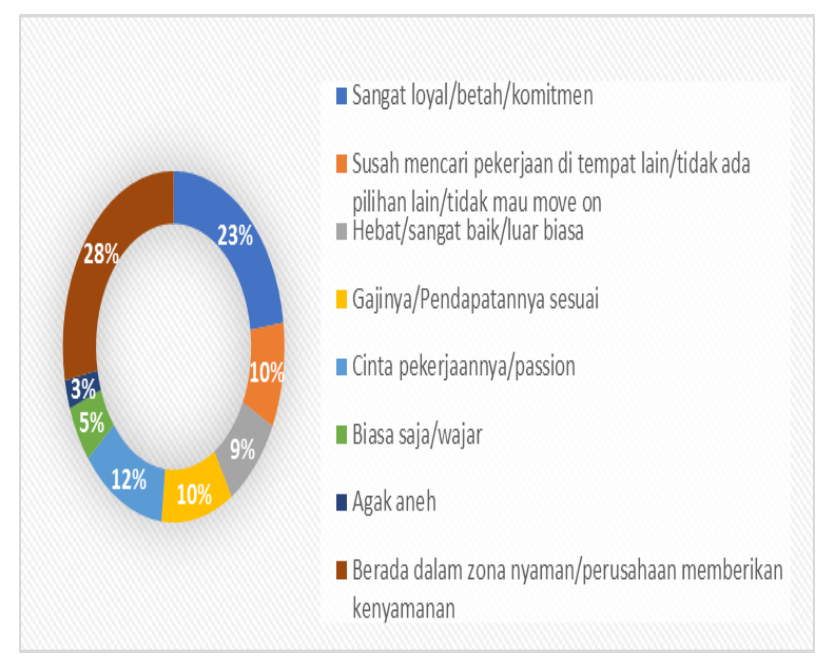

Gambar 8. Gen Y memandang karyawan yang bekerja > 5 tahun

di perusahaan yang sama

Gambar 7 dan gambar 8 menjelaskan bahwa dominasi pendapat terbesar para partisipan dari gen $\mathrm{X}$ atas fenomena tersebut adalah karyawan memiliki loyalitas dan komitmen pada perusahaan. Sedangkan pada gen $Y$ memandang fenomena tersebut sebagai karyawan yang berada dalam zona nyaman atau perusahaan memberikan kenyamanan pada perusahaan. Yang menarik dalam respon partisipan pada gen $Y$ atas pertanyaan ini adalah, bahwa gen $Y$ memandang karyawan yang berada di perusahaan yang sama lebih dari 5 tahun dikarenakan tidak ada pilihan lain dan susah mencari pekerjaan. Ada sekelompok partisipan dari gen $Y$ yang memandang karyawan tersebut aneh dan membuat gen $Y$ merasa takjub ada karyawan yang betah di satu perusahaan yang sama lebih dari 5 tahun. Hal ini tentu saja membuat perbedaan antara Generasi $\mathrm{X}$ dan Generasi $Y$ begitu berbeda.

Loyalitas yang dijelaskan sebagai kemauan atau keingingan karyawan untuk berada dalam perusahaan yang sama dalam kurun waktu tertentu dan bersedia bertindak dengan dilandasi oleh tujuan untuk mencapai tujuan besar organisasi/perusahaan. Hasil penelitian ini menjelaskan bahwa gen $X$ dan gen $Y$ memiliki pemaknaan pentingnya loyalitas karyawan yang berbeda secara signnifikan. Gen X menunjukkan makna loyalitas karyawan sebagai aspek yang lebih penting dibandingkan dengan gen Y. Sejalan dengan yang disampaikan Gravett dan Throckmorton (2007) bahwa pada dasarnya gen $X$ dan gen $Y$ memiliki derajat loyalitas yang cenderung sama, yaitu pertama loyalitas untuk keluarganya; kedua untuk diri mereka sendiri; ketiga untuk komunitas; keempat untuk rekan kerjanya dan kelima baru untuk employer (yang mempekerjakan mereka). Hal ini menjelaskan bahwa meskipun perbedaan pentingnya loyalitas di mata gen $X$ dan gen $Y$, namun bagi kedua generasi ini, memiliki loyalitas tidak semata kepada perusahaan atau yang mempekerjakan mereka.

Hasil penelitian ini menguatkan beberapa penelitian sebelumnya bahwa ketika gen $Y$ lebih mudah untuk disloyal dibandingkan dengan gen $\mathrm{X}$, karena gen $\mathrm{Y}$ tidak melihat bahw loyalitas dalam kontek pekerjaan ini menjadi hal yang perlu mendapatkan perhatian besar. Berbeda dengan gen $\mathrm{X}$ yang tumbuh dan berkemban dalam situasi yang lebih tidak stabil dalam dunia kerja, maka gen $\mathrm{X}$ memberikan pemahaman bahwa loyalitas dalam hal pekerjaan menjadi aspek yang penting untuk diperhatikan. Gen X menyaksikan dan mengalami sulitnya untuk mencari kerja, melihat banyaknya pemutusan hubungan kerja termasuk mungkin generasi orang tua gen $X$ yang mengalami. Dengan situasi yang ada ini, dalam diri gen $X$ tertanam pemahaman bahwa kontinuitas dan sustainability dari pekerjaan yang tercermin dalam keberadaannya dalam satu organisasi dalam waktu yang lama merupakan hal yang penting (Gravett \& Throckmorton, 2007).

Analisis tambahan dalam penelitian ini memberikan pemahaman yang lebih konkrit bahwa dalam gen $Y$ memiliki tantangan terkait dengan pekerjaannya. Hal ini terlihat, dibandingka gen $X$, gen $Y$ lebih berani untuk mengambil keputusan meninggalkan zona nyaman dan pindah ke tempat kerja lainnya. Dalam penelitian ini mencatat bahwa lebih dari $60 \%$ dari gen $Y$ mengalami pindah pekerjaan minimal dua kali. Dan sebaliknya untuk gen $X$ lebih dari $60 \%$ 


\section{Journal of Psychological Science and Profesion (JPSP)}

Vol.1, No.1, Desember 2017

E-mail: jpsp@unpad.ac.id

menyatakan tidak pernah pindah pekerjaan. Bila ditelusur lebih jauh dengan memerhatikan temuan lainnya dalam penelitian ini yang menyatakan alasan pindah kerja didominasi oleh factor pengembangan karir, adanya harapan untuk mendapatkan keamanan finansial yang lebih dan kenyamanan lingkungan kerja termasuk relasi dengan atasannya, maka penelitian ini mendukung peneliitian lainnya yang dilakukan oleh (Queiri, Yussoff, \& Dwaikat, 2014) yang menyatakan bahwa gen $Y$ memiliki tantangan yang besar dalam mencari karir yang cocok dengan passion dan work values yang dimilikinya.

Sementara itu, dari penelitian ini juga diperoleh informasi terkait dengan padangan gen $Y$ dan gen $X$ ketika melihaat ada seorang karyawan yang bekerja di tempat yang sama lebih dari lima tahun. Dara data yang yang terkumpul terlihat bahwa gen $X$ lebih positif memandang fenomena ini yaitu dengan menyampaikan adanya apresiasi seperti memiliki komitmen bagus, loyal terhadap perusahaan, puas dengan imbalan yang diberikan dan nyaman dengan lingkungan kerjanya. Gen $Y$ juga menyatakan hal yang sama dengan gen $X$ dalam hal loyalitas dan komitmen terhadap perusahaan, namun gen $Y$ memberikan beberapa tanggapan lainnya yang menimbulkan kesan lebih ke arah negative seperti tidak berani keluar dari zona nyaman, tidak dapat menyesuaikan diri dengan lingkungan baru, agak aneh, tidak ada pilihan lainnya dan tidak mau mencoba hal baru. Dari paparan data ini dapat dipahami bahwa dorongan gen $Y$ untuk eksplorasi lebih kuat dibandingkan dengan gen $X$. Gen $Y$ lebih mudah untuk memutuskan pindah kerja karena gen $Y$ tidak memandang bahwa kelekatan dengan rekan kerja dan perusahaan adalah aspek yang perlu dipertimbangkan. Hal ini sejalan dengan apa yang disampaikan oleh Weyland (2011) dari penelitiannya yang dilakukan di Malaysia, bahwa karyawan gen $Y$ sangat mudah memutuskan pindah kerja bila perusahaan menerapkan jam kerja yang ketat dan tidak fleksibel. Hal ini dikarenakan gen $Y$ mengutamakan keseimbangan antara kehidupan pribadi dan kehidupan kerja.

\section{SIMPULAN}

Tujuan dari penelitian ini adalah memberikan pemaknaan loyalitas karyawan gen $\mathrm{X}$ dan gen $\mathrm{Y}$. Hasil penelitian ini menjelaskan bahwa pemaknaan loyalitas karyawan yang diukur melalui pemaknaan tingkat kepentingan loyalitas karyawan bagi perusahaan memberikan infrormasi ada perbedaan yang siginifikan antara gen $\mathrm{X}$ dan gen $\mathrm{Y}$. Berdasarkan penggalian data yang lebih mendalam melalui kuesioner terbuka diperoleh informasi bahwa gen $Y$ memiliki pengalaman pindah kerja lebih sering dibandingkan dengan gen $X$ dan sebaliknya gen $X$ lebih banyak yang memiliki pengalaman tidak pernah pindah kerja. Gen $Y$ memberikan alasan untuk pindah kerja karena untuk orientasi pengembangan karir dan kenyamanan tempat kerja (waktu kerja tidak ketat, ada perimbangan dengan kehidupan pribadi).

Dengan memerhatikan hasil penelitian tersebut maka dapat dapat dipahami implikasi manajerial untuk pengelolaan karyawan di peruhaan. Perusahaan yang memiliki karyawan terdiri dari gen $\mathrm{X}$ dan gen $\mathrm{Y}$ hendaknya mulai mengkaji terkait dengan hal-hal yang mampu menjaga karyawan untuk tetap retain di perusahaan. Hal ini dikarenakan berkaitan dengan keberlangsungan dari perusahaan itu sendiri. Bila angka turnover meningkat sebagai akibat dari karyawan yang disloyal, maka perusahaan akan mengalami kesulitan untuk melakukan regenerasi atau suksesi pimpinan dalam perusahaan tersebut.

\section{DAFTAR PUSTAKA}

Ball, K., \& Gotsill, G. (2011). Surviving the Baby Boomers Exodus: Capturing Knowledge for Gen X dan Gen Y Employees.

Boston: Course Technology, a part of Cengage Learning.

Bettencourt, L. A., Gwinner, K. P., \& Meuter, M. L. (2001). A comparison of Attitude, Personality and Knowledge Predictors of Service-Oriented Organizational Citizenship Behavior. Journal of Applied Psychology, 86(1), 29 - 41.

Gravett, L., \& Throckmorton, R. (2007). Bridging the Generation Gap: How to Get Radio Babies, Boomers, Gen Xers and Gen Yers to Work Together and Achieve More. Franklin Lake: The Career Press Inc.

Hobart, B. (2016, Desember). Princeton One. Retrieved from Princeton One: www.PrincetonOne.com

Ismail, M., Rahim, A. N., Hou Lee, K., \& Tahir, N. F. (2016). Cultural Values and Career 


\section{Journal of Psychological Science and Profesion (JPSP)}

Vol.1, No.1, Desember 2017

E-mail: jpsp@unpad.ac.id

Goal of Gen-X and Gen-Y Employees: Evidence from Selected Malaysia Companies. Organizations and Markets in Emerging Economies, 7(2), 43 - 64.

Loyalty Research Center. (1990). Retrieved from www.loyaltyresearch.com

Meyer, J. P., \& Allen, N. J. (1991). A threecomponent Conceptualization of Organization Commitment. Human Resources Management Review, 1, 61 89.

Mowday, R. T., Porter, L. W., \& Steers, R. M. (1979). The Measurement of Organizational Commitment. Journal of Vocational Behavior(14), 224 - 227.

Mowday, R. T., Porter, L. W., \& Steers, R. M. (1982). Employee- origanization linkages. . New York: Academic Press.

Puteh, F., Kaliannan, M., \& Alam, N. (2015). Assessing Gen Y Impact on Organizational Performance: An Analysis from Top Management Perspective. Journal of Administrative Science, 12(1), 47 - 59.

Queiri, A., Yussoff, W., \& Dwaikat, N. (2014). Generation-Y Employees' Turnover: Work-Values Fit Perspective. International Journal of Business and Management, 9(11), 199 - 213.

Weyland, A. (2011). Engagement and talent management of Generation-Y. Industrial and commercial training, 43(7), 439 445.

Yigit, S., \& Aksay, K. (2015). A Comparison between Generation $X$ and Generation $Y$ in Terms of Individual Innovativeness Behavior: The Case of Turkish Health Profesionals. Individual Innovativeness Behavior: The Case of Turkish Health, 6(2), 106 - 117. 